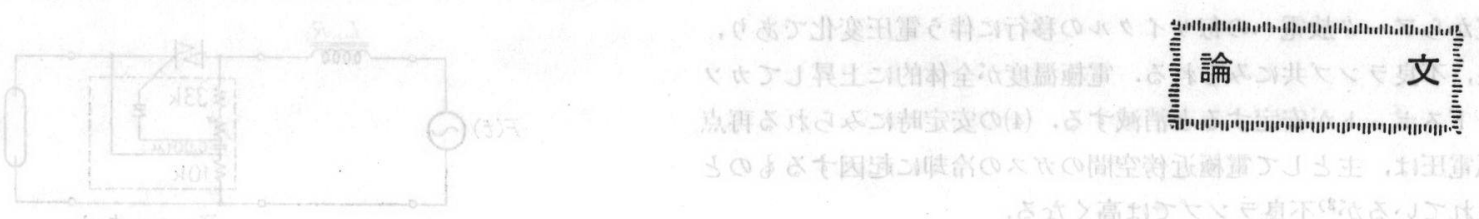

\title{
メタルハライドランプにおける再点弧電圧の抑制
}

専門会員井上昭浩*

\section{Suppression of Reignition Voltage in Metal Halide Lamps}

Akihiro Inouye (Fellow Member)

(Toshiba Cop.)

\begin{abstract}
Reignition phenomena in metal halide lamps during warm-up have been investigated.

Reignition voltage during warm-up can be suppressed by the following means.

(1) To dose excess metal into arc tube.

(2) To make raporization of mercury faster than that of metal halid-

(3) To put the inert gas at high pressures.

(4) To use heavy inert gas.
\end{abstract}

Two probes were set between two main electrodes and space potentials were measured at the moment when reignition occurred. Reignition voltage were measured using an arc tube of which electrodes gap was variable.

These experiments showed that reignition voltage grew uniformly in the electrodes gap.

\section{1. は じめに}

近年効率の高い HID ランプに物いて, 安定器を軽量小型化し 器具と一体的に組み合わせて用いることが多くなりつつある1). メタルハライドランプに括いても, 小型軽量な電子化安定器を器 具に組み込み, 屋内照明に用いることか゚今後多くなるものと予想 される.

しかしながら, メタルハライドランプはウォームアップ中に発 生する再点弧電圧のために立ち消える現象があり, 電流休止期間 の存在するよらな点灯方式では問題になる場合がある. そこで本 論文では, メタルハライドランプのウォームアップ中の再点弧現 象を観察吟味し，その抑制法について述べる。

\section{2. メタルハライドランプの再点弧現象}

メタルハライドランプに特ける再点弧現象は, 不純ガスの混入 した不良ランプの場合を図 1 に示すように,

(1) 始動後数サイクルないし数十サイクルまでにみられるもの

(2) 始動後 10 秒程度までにみられるもの

(3) 始動後 30 秒程度から 1～2 分までにみられるもの

(4) 安定点灯時にみられるもの

の 4 種類がある. (1)の始動後数十サイクルまでにみられる再点弧 電圧は，安定なカソードスポットを形成するまでの異常グロー放

* 榬東芝光源開発研究部

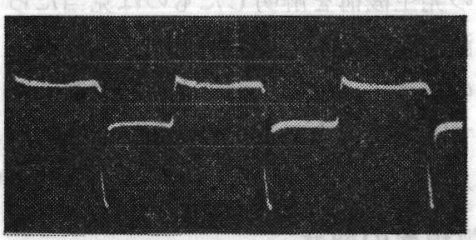

(1)

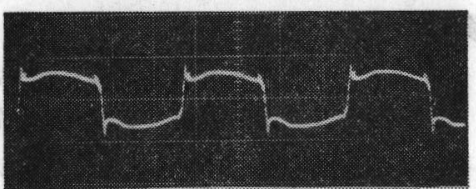

(2)

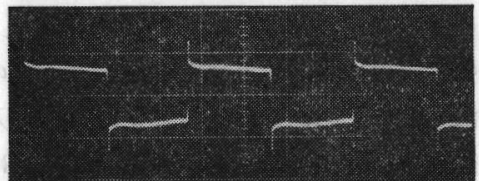

(3)

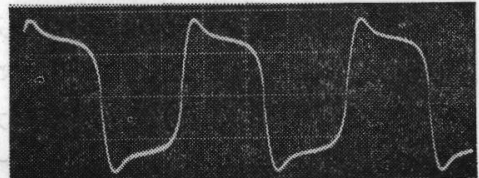

(4)

図1メタルハライドランプの再点孤現象 $300 \mathrm{~W}(\mathrm{Na}, \mathrm{Tl}, \mathrm{In} \perp 5$ 化物, Ne-1\% Ar 50 Torr $\left.<6.67 \times 10^{3} \mathrm{~Pa}\right\rangle$ ) 不良ランプの場合

（1）始動直後 $50 \mathrm{~V} / \mathrm{div}$ (2) 10 秒後 $50 \mathrm{~V} / \mathrm{div}$

(3) 30 秒後 $50 \mathrm{~V} / \mathrm{div} \quad$ (4) 5 分後 $100 \mathrm{~V} / \mathrm{div}$ 
電からアーク放電への每サイクルの移行に伴う電圧変化であり, 良, 不良ランプ共にみられる. 電極温度が全体的に上昇してカy ードスポットが安定すると消隇する. (4)の安定時にみられる再点 弧電王は, 主として電極近傍空間のガスの冷却に起因するものと されているが2)不良ランプでは高くなる.

本論文では, (2)招よび(3)の始動後数秒から 1 ～2 分までKみら れる再点弧電圧をそれぞれ第 1 再点弧電圧, 特よび第 2 再点弧電 圧と呼ぶことにし，この両再点弧電圧を扱う.

一般に放電現象の再点弧電圧発生機構には 2 原因が挙げられて いる.一つはカーボンアークのような場合に沶いて, ガス圧力あ るいは電極間距離を減少させていくと, 再点弧電圧がグロー放電 電圧に収束していく場合であり，これは電極部に起因する，今一 つはアーク長が長い場合に括いて, 空間中の荷電粒子の損失に大 さく影響される場合であり,この場合は空間部に起因する ${ }^{3)}$ (i

メタルハライドランプの再点弧現象に関しては, 始動後ウォー ムアップ中に高い再点弧電压が発生し, 立ち消える可能性がある こと ${ }^{4)}$, この再点弧電压は電流休止期間のあるリードピーク形安 定器に高く発生することが早くから見いだされている5゙.このよ らなランプを立ち消壳ることなく再点弧させるために必要な電圧 (Sustain Voltage または Recovery Strength) と, 電流休止直 前の電流変化率の関係も求められた6). このような再点弧電圧の 原因は，封入された過剩ハロゲンと反応したハロダン化水銀ら， あるいは $\mathrm{H}_{2} \mathrm{O}$ など7)によるるのであり, ランプ寿命中に高くな ることらが見いだされている，この再点弧現象を電極に起因する との立場から, ランプシミュレート回路により安定器特性を調査 したものである8.

このように欧米では, 安定器の多くが電流休止期間の存在する リードピーク形であるため, 早くからウォームアップ中の再点弧 が問題となり対策法も立てられてきたが，メタルハライドランプ の再点弧電圧の発生機構を解明したものは見当たらず, またラン プ自身の刘策法も少ない。

今後安定器の電子化, 位相制御による電力制御などが行なわれ るようになってくると再点弧電圧の抑制が必要となる. そこで次 章以下では再点弧電圧の発生機構とその抑制法について述べる.

\section{3. 再点弧現象の観察}

\section{1 实 験 方 法}

メタルハライドランプの再点弧電压は前章で述べたように, 不 純ガスの混入した発光管ほど高く現われる. また放電電流に休止 期間が長く存在するほど高くなる゚゙.したがって再点弧電圧の観 察には電流休止期間の存在するリードピーク形安定器がよいが, わが国ではこの型の安定器は非常に少ない。

そこで再点弧電压の出現を容易にし, どのタイプの発光管でも 適用でさる方法とするため, 放電電流休止期間を括入し再点弧電 圧を強調して観察する方法を採用した. 図 2 (a) にその回路構 成を示すが，両方向性サイリスタを位相制御することによって放 電灯に流れる電流に任意の時間, 電流休止期間を挿入し, その直 後の再点弧電圧を観察するものである. 図 2 (b) にはランプ電 压電流波形を図2（c）には電圧波形再点弧部分の払大図を示す.

本装置を使用して観察した例を 図 3, 図 4 に示す. 図 3 は電 流休止期間と第 2 再点弧電圧の関係を, 図 4 は電流休止期間 1 $\mathrm{ms}$ の場合の第 2 再点弧電圧の起動後の時間経過を示したもので

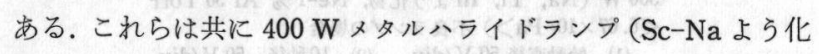
物, $\mathrm{Ne}-1 \% \mathrm{Ar} 50$ Torr $<6.7 \times 10^{3} \mathrm{~Pa}>$ 封入) についての結果で

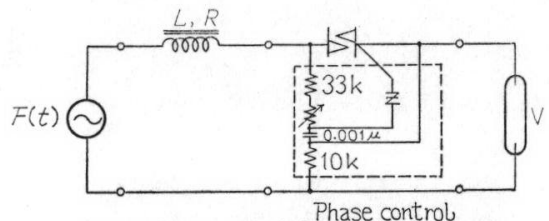

Phase control

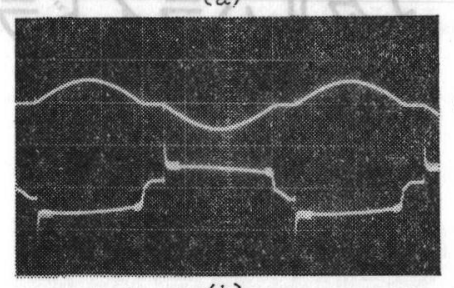

電流 $10 \mathrm{~A} / \mathrm{div}$ ランプ電压

$50 \mathrm{~V} / \mathrm{div}$

(b)

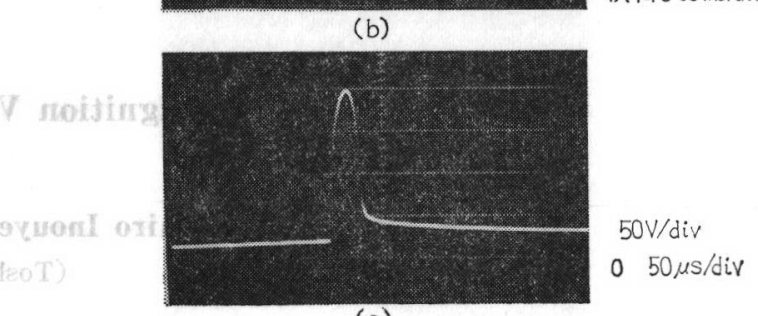

横軸 $3.33 \mathrm{~ms} / \mathrm{dir}$

2 再点弧電圧測定回路

(a) 测定回路 (b) 再点弧测定例

(c) 再点弧電王拡大図

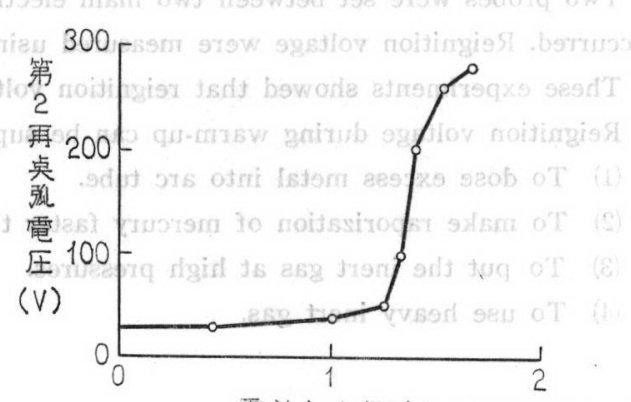

軋流休止期間 (ms)

图 3 電流休止期間と第 2 再点弧電压の間保 $(400 \mathrm{~W}$ 発光管, 始動後 30 秒での值)

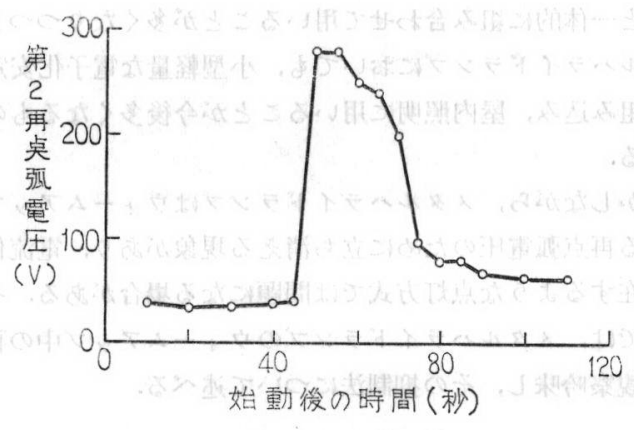

图 4 ウォームアップ中の再点听電庄の変化 （図 3 と同一発光管, 電流休止期間 $1 \mathrm{~ms}$ )

ある.な特本論文で実験に供した封入よう化物は,すべて米国 Anderson 社のものを使用している.

\section{2 再点弧電圧の発光管における発生場所}

本節では, メタルハライドランプのウォームアップ中に频ける 再点弧現象が電極部分に起因するものであるのか，または放電空 間に起因するるのであるのかを明らかにする.

図 5 に示す電極間距離を変えることのできる放電管に, $\mathrm{Ne}-$ $1 \% \mathrm{Ar}$ ガス 50 Torr $<6.7 \times 10^{3} \mathrm{~Pa}>$ を封入し, 電流休止期間を $0.5 \mathrm{~ms}$ としたときの再点弧電圧と電極間距離の関係を 図 6 に 


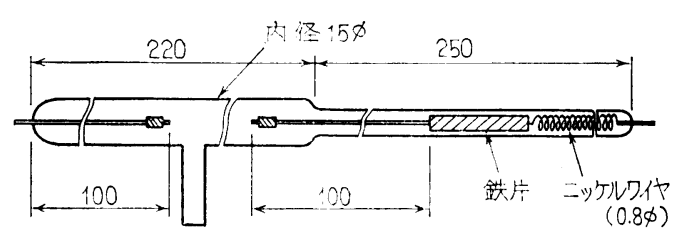

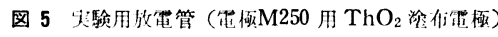

示す.よう化物拈よび水銀は封入されていないので，定常点灯状 態の再点弧電压は, メタルハライドランプの第 1 再点弧電压に相 当することになるが，ほほ原点を通る直線上に乗っている．した がって再点弧現象は放電空間全体にわたって作用しており，電極 部分あるいはその近傍に招ける現象ではないことがわかる。

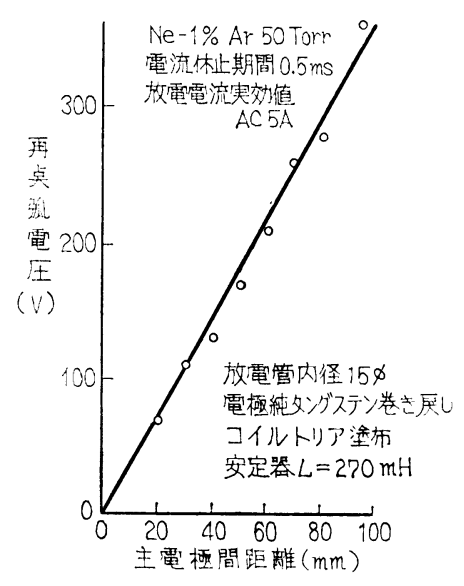

図 6 電極間距䨀と再点胍電压

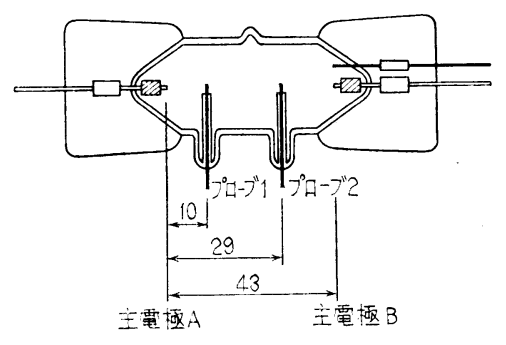

図 7 测定用放電管 $(400 \mathrm{~W})$

$\mathrm{Hg} 64 \mathrm{mg}, \mathrm{HgI}_{2} 5 \mathrm{mg}, \mathrm{Ar} 25$ Torr 封入

図 7 に示すようなプローブを 2 本挿人した $400 \mathrm{~W}$ 発光管に $\mathrm{Hg}$ $64 \mathrm{mg}, \mathrm{HgI}_{2} 5 \mathrm{mg}, \mathrm{Ar} 25 \mathrm{Torr}<3.3 \times 10^{3} \mathrm{~Pa}>$ を封入し, 電流 休止期間 $1 \mathrm{~ms}$ にて始動75秒後の瞬間の再点弧電圧（ランプ電圧 波形の肩部の電生も含豆）と，アーク放電時のランプ電圧（波形 の肩の部分）扣よび 2 本のプローブのそれぞれの主電極 $\mathrm{A}$ を基準 とした電位を表 1 に示す. ランプ電压およでプローブ電压は東

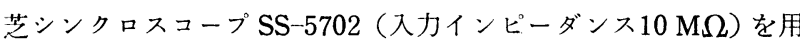
いた．したがってプローブ電流はごく微少であり，プローブ電位 はほぼフローティングポテンシャル(絶縁電位)に近い。すなわち 放電空間内のプローブ位置に劣けるプラズマポテンシャルと，プ

表 1 再点弧時拉よびアーク放電時の各部の䉓位

（主電極 $\mathrm{A}$ を基溸とし，主電極Bが陰極の半サイクルでの值）

\begin{tabular}{|c|c|c|c|c|c|}
\hline & $\begin{array}{c}\text { 主䉓極 } \\
\mathrm{A}\end{array}$ & $\mid \begin{array}{c}\text { プロ-フ } \\
1\end{array}$ & $\begin{array}{c}\text { プローブ } \\
2\end{array}$ & $\begin{array}{c}\text { 主䉓極 } \\
\text { B }\end{array}$ & 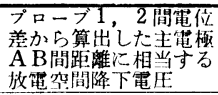 \\
\hline $\begin{array}{c}\text { 再点坬時(再点㧓電圧) } \\
(\mathrm{V})\end{array}$ & 0 & -90 & -220 & -290 & $294 \mathrm{~V}$ \\
\hline 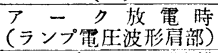 & 0 & -9.2 & -11.4 & 約 -30 & $5 \mathrm{~V}$ \\
\hline $\begin{array}{c}\text { 主電極 } \begin{array}{c}\mathrm{A} .5 \\
(\mathrm{~mm})\end{array} \\
\end{array}$ & 0 & 10 & 29 & 43 & \\
\hline
\end{tabular}

ローブの示す電位との差は, 阿ブローブでほ注等しいとみなし得

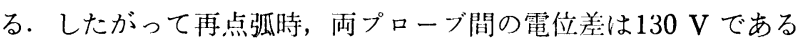
から電極問空間では $294 \mathrm{~V}$ の電位差となる。一方洏電極間の電位 差は $290 \mathrm{~V}$ であり, 第 2 再点弧の場合も放電空間内でほぼ一様に 作用しているといえる.なお再点弧後は表 1 のアーク放電時のラ ンプ電压から, 陽光柱部 $5 \mathrm{~V}$, 陽陰極降下電压約 $25 \mathrm{~V}$ となる.

\section{3 再点弧電圧の挙動}

第 1 および第 2 再点弧電不が，他の放電特性とどの上うな関係 にあるかを知ることは再点弧電圧の原因解明に重要である。本節 では不純ガスの程度, 封入物の取り扱い才之どのような関係にあ るかその挙動について述べる.

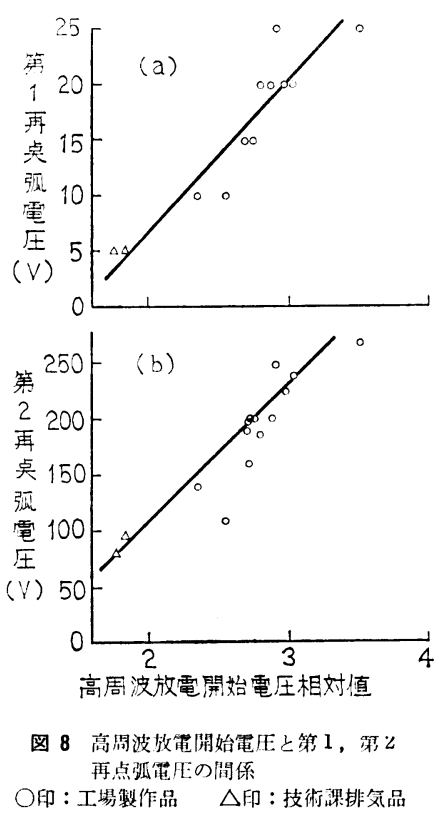

まずメタルハライドランプ発光管（電極間距離 $80 \mathrm{~mm}$, 発光管 内径 $25 \mathrm{~mm}, \mathrm{Sc}-\mathrm{Na}$ 上万化物, $\mathrm{Ne}-1 \%$ Ar 50 Torr $<6.7 \times 10^{3}$ $\mathrm{Pa}>$ の不純ガス混入程度を示す高周波放電開始電压 ${ }^{10)}$ と, 再点 弧電压の関係を図 8 に示す. (a)は第 1 再点弧電压を, (b) は第 2 再点弧電圧を示す，本図の場合は再点弧電圧のパルス状の部分だ けの高さを示しており, 再点弧した後のランプ電圧を差し引いて いる.これらの発光管は製作後15分程度の枯化点灯を行なった後 のものであり, 第 1 再点弧電圧は始動後 10 秒の, 第 2 再点弧電圧 は始動後 30 秒での值であり電流休止期間は $1 \mathrm{~ms}$ である.このよ らに製作直後の段階では, 高周波放電破壊電圧で示される不純ガ ス濃度と第 1 および第 2 再点弧電生は対応している.

高周波放電破壊電压の高い発光管のグロー放電発光スペクトル を観察すると， $\mathrm{HgH} ， \mathrm{OH}, \mathrm{I}$ などの不純ガススペクトルがみられ る.このような発光管を十数時間枯化点灯すると高周波放電破壊 電压，第 1 再点弧電圧および商用周波電源での始動電圧が 低下 し, 図 8 の $\triangle$ 印程度のレベルに改善される. そしてグロースペク トル中の $\mathrm{HgH}, \mathrm{OH}$ 強度も減少し，観測でさない程度に改善され る.しかしながら第 2 再点弧電圧はほとんど改善されず，グロー スペクトル中のIラインも減少しない。

このように，第 1 再点弧電压は不純ガスとしての $\mathrm{H}_{2}, \mathrm{H}_{2} \mathrm{O}$ な どに強く左右されるものであり，高周波放電破壊電压および商用 周波電源での始動電压ともよく対応している.

実際 $\mathrm{Sc}-\mathrm{Na}$ よう化物 $20 \mathrm{mg}$ を半日大気中に放置した後, $400 \mathrm{~W}$ メタルハライドランプ発光管に封入し，排気管内に $80 \mathrm{mg}$ の Ti 
板を挿入し, 発光管を 30 分間ずつ $500^{\circ} \mathrm{C}$ に加熱し, 商用周波電源 による始動電圧，および第 2 再点弧電圧を測定した結果が 表 2 である．始動電压を押し上げる不純ガスは $\mathrm{Ti}$ ゲッタによって吸 着されるが，第 2 再点弧電圧を押し上げる要因は改善されていな い.

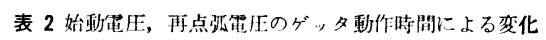

\begin{tabular}{|c|c|c|c|}
\hline 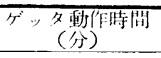 & 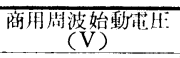 & 符 2 再点孤笛生 & 业 \\
\hline 0 & 300 以上 & - & \\
\hline 30 & 260 & $250 \mathrm{~V}$ 以上 30 秒立ち消え & $\mathrm{HgI}_{2}$ 赤色結晶 \\
\hline 60 & 195 & " & " \\
\hline 90 & 175 & " & " \\
\hline
\end{tabular}

表 3 封入上5化水銀量と再点弧電压の間倸

\begin{tabular}{|c|c|c|c|c|c|c|}
\hline \multirow{2}{*}{ ランプ No. } & \multirow{2}{*}{$\begin{array}{l}\mathrm{Hg} \text { 量 } \\
(\mathrm{mg})\end{array}$} & \multirow{2}{*}{$\begin{array}{c}\mathrm{HgI}_{2} \text { 显 } \\
(\mathrm{mg})\end{array}$} & \multirow{2}{*}{ ガ ス 帛 } & \multirow{2}{*}{$\begin{array}{c}\text { 始動電压 } \\
\text { (V) }\end{array}$} & \multicolumn{2}{|c|}{ 第 2 再点孤 } \\
\hline & & & & & $\begin{array}{l}\text { 繁大䛧 } \\
\text { (V) }\end{array}$ & $\begin{array}{c}\text { その時閂 } \\
\text { (秒) }\end{array}$ \\
\hline 1 & 65 & 1 & Ar 25 Torr & 180 & 52 & 90 \\
\hline 2 & 65 & 5 & " & 200 & 立七消え & 80 \\
\hline 3 & 70 & 0 & $\begin{array}{c}\mathrm{Ne}-1 \% \\
\mathrm{Ar} 50 \text { Torr }\end{array}$ & 150 & 40 & 55 \\
\hline
\end{tabular}

Waymouth は, 筑 2 再点弧電压の原因を $\mathrm{HgI}_{2}$ であるとしてい るが11), 実際表 3 に示すように $400 \mathrm{~W}$ 発光管に $\mathrm{HgI}_{2}$ と $\mathrm{Hg}$ を $\operatorname{Ar} 25$ Torr $<3.3 \times 10^{3} \mathrm{~Pa}>$ とと为に封入することにより, 第 2 再 点弧電圧が上昇する. また表 2 に示した大気中放置よう化物封入 発光管をいちど加熱すると, $\mathrm{HgI}_{2}$ のものとみられるやや赤みを帯 びた結晶が管壁に析出してくる.

これらの現象はよう化物の持ち込む水分が分解, 解離し, $\mathrm{O}_{2}$ は $\mathrm{ScI}_{3}$ と反応し $\mathrm{Sc}_{2} \mathrm{O}_{3}$ と遊離 $\mathrm{I}_{2}$ を形成し, この遊離した $\mathrm{I}_{2}$ が $\mathrm{Hg}$ と結合して $\mathrm{HgI}_{2}$ になるものとみられる. したがって発光管製造 直後は図 8 に示したように第 1 再点弧電压あるいは, 始動電厈そ して第 2 再点弧電玉とは，一義的に高周波放電破壊電压と結びつ いている. しかしながら数時間の枯化点灯により $\mathrm{H}_{2}$ などが吸着 されて，始動電压あるいは第 1 再点弧電压が低下するのに対し て, $\mathrm{HgI}_{2}$ は残留し, 第 2 再点弧電圧は改善されないままとなる のである.

\section{4. 再点弧電圧に対する理論的アプローチ}

再点弧電压を抑制するためには，その発生機構を知ることが必 要である. 本章では再点弧電压発生機構に対し一つの理論的アブ ローチを試みる.

電源電厈波形 $F(t)$ に対して, チョーク安定器のインダクタン スを $L$, 抵抗を $R$, 電流を $i$, ランプ電压を $V_{l}$ とすると次式が成 立する.

$$
L \frac{d i}{d t}+R_{i}+V_{l}=F(t)
$$

発光管電極間距離を $d$, 陽侩極降下電圧を $V_{c}$, 発光管断面積を $S$, 軸方向電界強度を $E$, 電子密度を $n_{e}$, 電子移動度を $\mu$ とす ると

$$
\begin{aligned}
V_{l} & =V_{c}+E \cdot d \\
i & =n_{e} e S \mu E
\end{aligned}
$$

である. $\nu_{i}, \nu_{\mathrm{loss}}, D_{a}, \Lambda$ をそれ゙れ電離周波数, 抁散以外の電 子損失, 河極性抎散倸数, 昖散特性脣として次式が成立する.

$$
\frac{1}{n_{e}} \frac{d n_{e}}{d t}=\nu_{i}-\left(\frac{D_{a}}{\Lambda^{2}}+\nu_{\mathrm{loss}}\right)
$$

以上四つの式によって, 再点弧時のランプ特性を求めることがで きる。

式(3)を微分し整理すると次式を得る.

$$
\frac{1}{n_{e}} \frac{d n_{e}}{d t}=\frac{1}{i} \frac{d i}{d t}-\frac{1}{E} \frac{d E}{d t}
$$

電流休止期間 $t_{\text {off }}$ の間は発光管に電圧は加わらないから，(4)式の

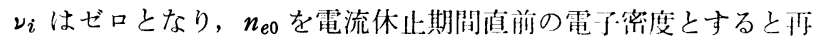
点弧時の電子密度は次式となる.

$$
n_{e}=n_{e 0} \exp \left[-\left(\frac{D_{a}}{\Lambda^{2}}+\nu_{\text {loss }}\right) t_{\text {off }}\right]
$$

ここで再点弧現象を, 電子密度增加率がある值 $C$ 以上になり, そのとき $d E / d t=0$ となって再点弧するものであると仮定すると (5)式から

$$
\frac{1}{n_{e}} \frac{d n_{e}}{d t}=\frac{1}{i} \frac{d i}{d t}=C
$$

を得る。これを(1)式に代入し次式を得る。

$$
C=-\frac{R}{L}+\frac{1}{L} \frac{F(t)-V_{l}}{i}
$$

任意の再点弧電压值 $V_{l}$ に対して, 上式 $C$ がある固定值をとるた めには $C=0$ が必要である. すなわち $C$ が 0 でない場合には(1)式 から, あるいは(8)式から理解されるように異なる $V_{l}$ に対して異 なる $C$ 值をとり, 再点弧現象はある固定值 $C$ で起きるとした仮定 に反する． $C=0$ の場合には(1)式は図 2 (a)の回路において静的, すなわち, 直流的電流電圧条件として任意の $V_{l}$ に対して成立す る. この $C=0$ が再点弧条件であることは(4)式からも容易に理解 できる.

$$
\frac{1}{n_{e}} \frac{d n_{e}}{d t}=\frac{1}{i} \frac{d i}{d t}=\frac{1}{E} \frac{d E}{d t}=0
$$

が再点弧時の条件となる.

式(1)に(2)，(3)，(6)，(9)式を代入し次式を得る.

$$
\begin{aligned}
& \ln _{n}\left\{\frac{F(t)-V_{l}}{V_{l}-V_{c}}\right\} \\
& \quad=-\left(\frac{D_{a}}{\Lambda^{2}}+\nu_{\text {loss }}\right) t_{\mathrm{off}}+l_{n}\left\{n_{e 0} e S \mu R d\right\}
\end{aligned}
$$

上式右辺第 1 項は, 電流休止期間中の電子密度の減少程度を表わ すものであるから, 右辺第 1 項の $n_{e 0} \mu$ が一定とみなし得る場合 には左辺は電流休止期間 $t_{\text {of } \mathrm{f}}$ だけの関数となる. 回路的手段によ って電流休止直前の $n_{e 0} \mu$ ，すなわち(3)式における $i / E$ を一定と することは可能であるから, 横軸に $t_{\text {off }}$, 縦軸に $l_{n}\left[\left(F(t)-V_{l}\right) /\right.$ $\left.\left(V_{l}-V_{c}\right)\right]$ をとれば直線的関係が得られ，その傾きが電子の損失 係数を与えることになる.

表 3 の $\mathrm{HgI}_{2}$ 封入ランプ, および実際のメタルハライドランプ (Sc-Na よう化物 $30 \mathrm{mg}, \mathrm{Hg} 55 \mathrm{mg}$ 封入) の電流休止期間と, 第 2 再点弧電圧最大值の関係を 図 9 に示し, これから電流休止期 間 $t_{\text {off }}$ と $l_{n}\left[\left(F(t)-V_{l}\right) /\left(V_{l}-V_{c}\right)\right]$ との関係を图 10 に示す. 図 9 から図10への変換に際し, $V_{l}$ は各 $t_{\mathrm{off}}$ に対応した再点弧電 圧を用い, $V_{c}$ として $t_{\mathrm{off}}=0$ のときのランプ電圧を用い, $F(t)$ は 電源電压の再点弧位相での值を用いている.この場合

$$
D_{a} / \Lambda^{2}+\nu_{\text {loss }}=3.4 \times 10^{3}\left(s^{-1}\right)
$$

を得る.ここでは(10)式で与えられる $n_{e 0} \mu$ を一定に保つことは行 なっていないが, 図10で示されているようによく直線に乗ってお り，(10)式の成立を裏付けるものと考兄られる.

このように再点弧時に(9)式の成立を仮定することにより, 再点 


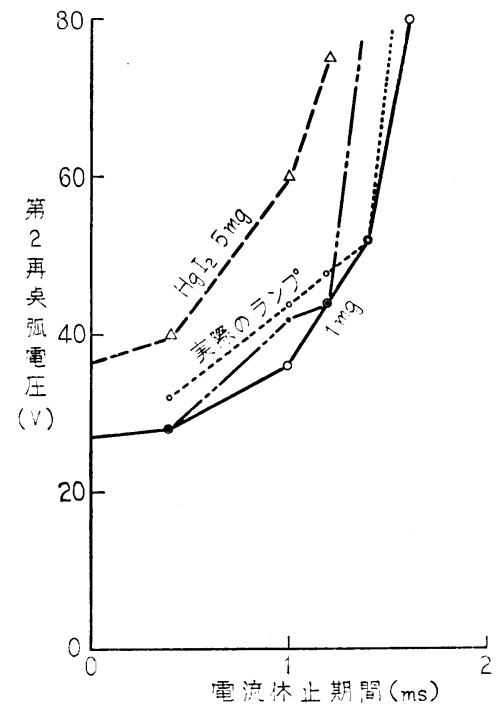

图 9 奄流怵1:期間と第 2 再点弧電压の閒係 $400 \mathrm{~W}$ 焱光管

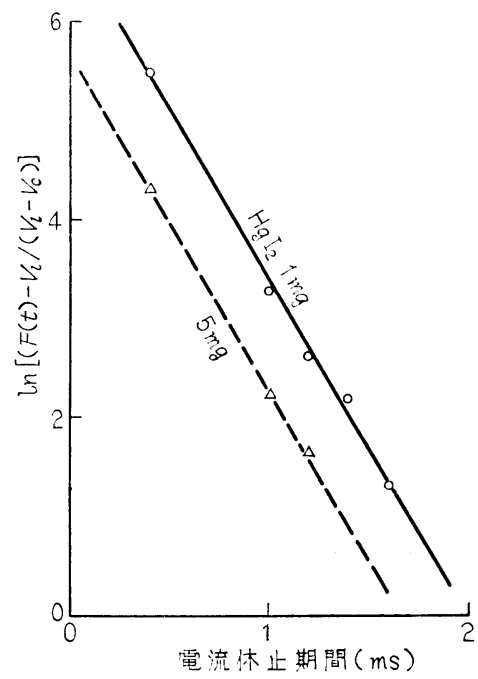

図 10 電流休止期間と $l_{n}\left[\left(F(t)-V_{l}\right) /\right.$ $\left(V_{l}-V_{c}\right)$ ] の間係

弧現象と電子損失の関係を予想することができる.電離過程が電 子との直接衝突電離であれ, あるいは累積電離などの間接電離過 程であれ，電子損失を補うために必要な電子エネルギー供給が, 電子加速のための再点弧電圧として出現してくることになる.

前章で述べたよらに, 発光管ウォームアップ中の再点弧現象は 放電空間に起因している. このような現象が起きる機構として は，電子・イオンの拡散・付着などに基づく損失による場合のほ かに累積電離脱励起過程による場合がある. すなわち励起 $\mathrm{Hg}$ 分 子の累積電離を不純ガスが妨げるとき, 微少電流域で高い電圧が 発生することが報告されている ${ }^{12) 13)}$. 水銀の存在する場合には再 点弧時この累積電離脱励起現象が起きていると推定される.

式(10)では電子損失と再点弧電圧との関係を扱っており, 累積電 離脱励起などによる再点弧電圧変化分をも，電子損失として表示 している. 純粋な電子損失による作用分と累積電離脱励起などに よる作用分の分離評価は今後の課題である.

本章の展開に打いて(9)式の成立が仮定されているが，(9)式が成 立しない場合, すなわち再点弧時(8)式において時々刻々個々のC の值をとる場合には今までの考察は適用できない, 再点弧時, 電
流休止期間の長さに応じて(8)式 $C$ の值が变わり得るかどうか, 変 わる場合には，再点弧現象をどう定量的に扱うべきかについても 今後の課題である.

\section{5. 再点弧電圧の抑制}

第 1 再点弧電压は室温で気休状の不純物，たとえば $\mathrm{H}_{2}$ などに よって発生するものであることは, 図 8 の結果および 3.3 節で述 べた事柄から明らかである。この不純がスの除去は発光管排父䏡 の十分な加熱脱ガス処理あるいは，排父管中に Ti などのゲッタ を封入し加熱動作させることなどにより容易に行ない得る.

第 2 再点弧電圧の抑制については， $\mathrm{HgI}_{2}$ の生成を防止するた めに過剩金属を封入する方法がある ${ }^{11)}$. 実際 $400 \mathrm{~W}$ 用発光管に $\mathrm{HgI}_{2}$ と $\mathrm{Sc}$ メルを封入した場合は, 約 30 分の点灯で $\mathrm{ScI}_{3}$ の形 成によって $\mathrm{HgI}_{2}$ が消失し第 2 再点弧電圧が減少する.

再点弧時には(4)式で

$$
\nu_{i}-\left(\frac{D_{a}}{\Lambda^{2}}+\nu_{\text {loss }}\right)=0
$$

であるとした。ごく短時間の間ではあるが電子の生成と消隇とが バランスしているとみなした。 この場合には電子エネルギー損失 增加率 $\left(E^{2}-E_{0}^{2}\right) / E_{0}^{2}$ が, 不純ガス相対濃度に比例することか $ら^{14) 15)}$, 不純ガス相対濃度を低下させるべくガス圧（この場合は 水銀蒸気圧）を增加させればよいことになる．すなわち不純ガス よりも早く水銀を蒸発させればよいことになる．また電子損失を 少なくすればよいことから封入希ガス圧を高くすること, 封入希 ガスのらち原子量の大きいものを用いれば, 再点弧電圧を抑制す ることができると予想される。

図 11 に始動用希ガスとしての Xe 圧を变えた場合の $400 \mathrm{~W}$ 発 光管の第 2 再点弧電圧, および Ar 25 Torr $<3.3 \times 10^{3} \mathrm{~Pa}>$ の場 合のそれを示す. 電流休止期間は $1 \mathrm{~ms}$ 扎よび $2 \mathrm{~ms}$ である. ガ ス圧が高いほど，またガスが重いほうが第 2 再点弧電厈が低くな っており理論的予測に合致する.

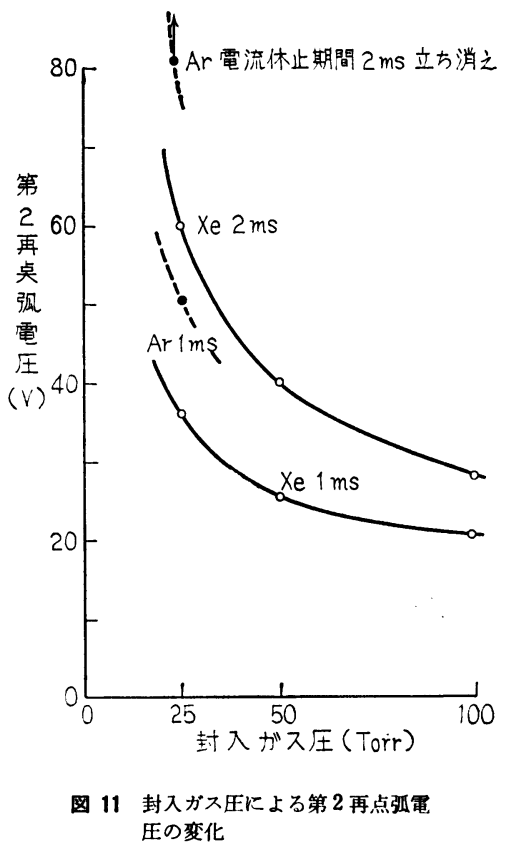

図 12 に示すような 3 層コイル電極を， $1 \mathrm{~kW}$ メタルハライド ランプに採用した結果, 第 2 再点弧電圧は平均 $93 \mathrm{~V}$ と従来の 2 層コイル電極の場合の平均 $262 \mathrm{~V}$ に対して相当抑制されている. 


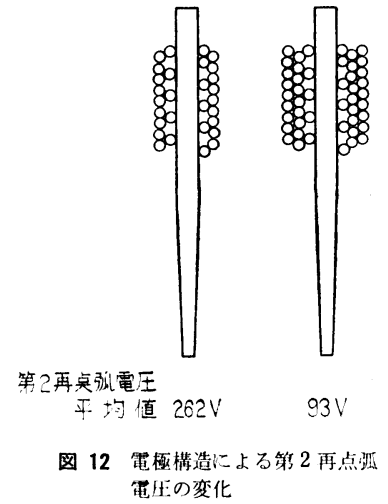

この電極を用いた発光管を垂直点灯し管壁温度を湘定した結果， 下方電極近傍の管壁温度が，従来電極を用いたものより約 $50 \mathrm{~K}$ 上昇していた．このことはランプ消灯後の発光管冷却中によう化 物の電極江傍への凝縮が少なくなり，ランプ始動時よう化物の蒸 発よりも水銀の蒸発が早く行なわれ，結果的に第 2 再点弧電压が 低下するものと推定される．これに類した例として発光管径を太 くすることにより第 2 再点弧電压が 低下寸る 現象がある. $1 \mathrm{~kW}$ 発光管の例では発光管直径を $25 \mathrm{~mm}$ から $30 \mathrm{~mm}$ とし, 電極間距 離を $80 \mathrm{~mm}$ から $70 \mathrm{~mm}$ に変更することにより, やはり電極近傍 の管壁温度が約 $50 \mathrm{~K}$ 程度上昇し，变更前平均 $262 \mathrm{~V}$ の第 2 再点

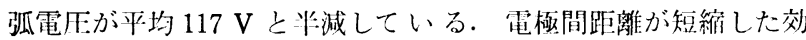
果，管径が太くなったことによる効果で，直接第 2 再点弧電压が 低下寸ることのほかに，水銀とよう化物の蒸気速度の差の効果が あるものと推定される。

同一発光管に拈いても，水平点灯した場合と椟点灯した場命

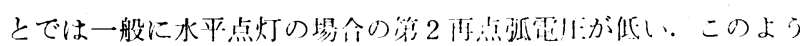
に水銀のよら化物の蒸発する早さの制御に上り，第 2 再点弧電压 を抑制できる.

\section{6. 結 論}

メタルハライドランプのウォームアップ中に発牛する再点弧現 象が不純ガスに起因するものであることを確涩するとともに，そ の抑制法について述べた.

本実験で得られた事柄をまとめると次のとおりである.

(1) 製作直後の発光管においては, 第 1 および第 2 再点弧電压 は初期持ち込み不純ガス濃度と対応する. しかしながら数十時間 の枯化点灯によって第 1 再点弧電压は減少するのに対して, 第 2 再点弧電压は不変である.

(2) メタルハライドランプのウォームアップ中に就る再点弧 現象は電極近傍での現象ではなく放電空間での現象であり，放電 空間全体にわたって一様な現象である.

（3）放電電流を短時間休止させ，再点弧現象を誇張して観察し た結果, 電流休止期間 $t_{\text {off }}$ と $\left.l_{n}\left[F(t)-V_{l}\right) /\left(V_{l}-V_{c}\right)\right]$ とは直線 的関係にあり，この傾きは電子損失係数を与える.

（4）ウォームアップ中の再点弧電压を抑制することは,

（价過剩金属の封入によりハロゲン化水銀の分解消失を図る.

(口) 電極近傍管壁温度を上昇させる.

（父）封入希ガス压を高くする.

(二) 封入希ガス原子量を增大させる.

などによって達成することができる.

これらの技術は電子安定器などの将来の点灯方式に対して, ウ オームアップ中の立ち消觉に対するランプサイドからの有力な防
止手段を与光得るものである.

終わりに，本研究に対して有益なる助言をいただいた京都大学 電子工学教室板谷良平教授に深謝の意を表する。ま心奏験の遂行 に際して東芝光源”睽研究部持丸真次氏，佐々ボ溥基氏にはご援 助いただいた。ここに記して謝意を表する。

参 考 文 献

（1）非山博之, 小山敦夫，赤塚美律雄，小松春樹：小出力高蛽 ナトリウムランプの毎サイクル点弧形電子安定器による点 灯, 照学誌 67-7 (昭58) 266

(2) Kern, J.: Deutung der elektrischen Eigenschoften der mit Wechselstrom betriebenen Hochdruckentladung aus den Vorgängen an den Elektroden, Technisch Wissenschaftliche Abhandlungen der Osram Gesellschaft 5 (1943)

(3) Cobine, J.: Gaseous Conductors, Dover Publications, Inc. New York (1958)

(4) Cohen, S.: Ballasting the New Metallic-Additive Discharge Lamps, IES Tech. Conf. Preprint (1965) No. 28, 同 Illum. Engng. 11 (1965) 660

(5) Franke, A, Gungle, W. C., Ring, J. F. and Waymouth, J. F. : Reignition Characteristics of Metal Halide Lamps and their Effect on Ballast Design, IES Tech. Conf. Preprint (1966) No. 11

(6) Lake, W. H. and Kramel, L. F.: Capability Criferia batween Metal Iodide Lamps and Ballasts, IES Tech. Conf. Preprint (1967)

（7）伊藤三郎, 青木 照：メタルハラドランプの再点弧ピーク に関する考察，照学全大（炤45）19

(8) Partlow, W. D.: The Interaction of Metal Halide Lamps and Ballasts during Reignition, IES Tech. Conf. Preprint (1979) No. 28, 同 J. Illum. Engng. Soc. 10-2 (1981) 114

(9) Martt, E. C., Smialek, L. J. and Green, A. C.: Iodides in Mercury Arcs-For Improved Color and Efficacy, IES Tech. Conf. Preprint (1963) 同 Illum. Engng. 19 -1 (1964) 34

(10) Terashima, Y., Inoue, A. and Ogawa, K.: Effects of quenching reactions on the breakdown voltage in $\mathrm{Ar}^{-}$ Hg Penning mixture, J. Light Vis, Environ. 2-1(1978)2

(11) Waymouth, J. F.: Electric Discharge Lamps, Cambridge MIT Press (1971)

(12) Yamane, M., Suenaga, M. and Miyashita, T.: Breakdown mechanism of metal halid, lamps, J. Light Vis. Environ. 2-1 (1978) 9

(13) 井上昭浩：メタルハライドランプの始動に及ぼす不純ガス の影響, 電気学会放電光応用視覚合同研究会資料 ED-8026, LAV-80-2（昭55）

(14) 井上昭浩 : 放電ランプの始動に及ぼす不純ガスの影響, 照 学誌 62-11 (昭53) 588

(15) Inouye A.: Effects of impurity gases on lamp starting mechanism, J. Light Vis. Environ. 2-2 (1978) 6

（受付1983年12月27日） 